\title{
Development Strategy of Seaweed Aquaculture Business in Kupang Regency, East Nusa Tenggara Province, Indonesia
}

\begin{abstract}
Sunadji
Doctoral Program Faculty of Fisheries and Marine Sciences University of Brawijaya - Malang Indonesia
\end{abstract}

Muhammad S

Faculty of Fisheries and Marine Sciences University of Brawijaya - Malang Indonesia

Tjahjono A

Faculty of Fisheries and Marine Sciences University of Brawijaya - Malang Indonesia

Riniwati $\mathrm{H}$

Faculty of Fisheries and Marine Sciences University of Brawijaya - Malang Indonesia

Received: September 23, 2013 Accepted: October 9, 2013

doi:10.5296/jas.v2i1.4631 URL: http://dx.doi.org/10.5296/jas.v2i1.4631

\begin{abstract}
Seaweed is a main commodity in fisheries revitalization plan other than shrimp and tuna because it has some excellence, such as: export opportunities that are widely opened, price that is relatively stable, absence of trade quota for seaweed; simple cultivation technology that makes it easy-learned; short-term of cultivation cycle that gives profit fast; small amount of capital needs; seaweed belongs to unchangeable commodity because it has no synthetic changes; seaweed aquaculture is considered as labor-intensive business that requires some labors. Kupang Regency has potential area for seaweed aquaculture by 10.354,07 ha and newly-utilized area by $10 \%$ in 2010. Seaweed aquaculture business in Kupang Regency is conducted by home industry. Government policy which is represented by Fisheries and Marine Services of Kupang Regency is still partially implemented. This study aims to acquaint
\end{abstract}


development strategy of seaweed aquaculture business in Kupang Regency, East Nusa Tenggara Province, Indonesia. Applied research method is survey, population of seaweed cultivators, while the applied data analysis is SWOT analysis. Result of analysis based on SWOT analysis shows that development of seaweed aquaculture ranks in first quadrant position meaning that applied strategy is Progressive or Aggressive strategy. Progressive development strategy of seaweed business can be carried out by: production harvest escalation, quality and continuity of seaweed increase, labor increment and area utilization, as well as government role increment in capital and institutional development.

Keywords: Strategy, Seaweed, Aquaculture, Business, Development

\section{Introduction}

Seaweed becomes strategic commodity in fisheries revitalization plan other than shrimp and tuna. Territory area owned by Indonesia for seaweed aquaculture is 1,110,900 ha, but the development of seaweed aquaculture still utilizes an area of 222,180 ha (20\% of potential area width). The most favorite kinds of seaweed in market are Euchema spinosum, Euchema cottonii and Gracilaria sp (Afrianto and Liviani, 1989). In addition for being food source, based on research, seaweed may be utilized as energy sources, that is an ingredient for biofuel (Numberi, 2008). The presence of seaweed as an alternative energy source is a new thing that should be supported and developed. Microalgae as biodiesel is assessed as more competitive than the other commodities. It is said that 1 ha area of microalgae produces 58,700 litre (30\% in form of oil) per year or it's amount is more than corn product (172 liter/year) and oil palm product (5.900 liter/year) (Direktorat Jenderal Perikanan Budidaya, 2011). Else, development of seaweed as energy source does not emerge new problem because seaweed does not belong to daily consumed food and does not spend much time to be cultured. Hence, the presence of seaweed is not only for food source but also energy source and cosmetic industry that should be promoted continuously.

Seaweed belongs to the main commodity in fisheries revitalization plan other than shrimp and tuna (Direktorat Jenderal Perikanan Budidaya, 2010), because it has some excellence, such as: export opportunities that are widely opened, price that is relatively stable, absence of trade quota for seaweed; simple cultivation technology that makes it easy-learned; short-term of cultivation cycle that gives profit fast; small amount of capital needs; seaweed belongs to unchangeable commodity because it has no synthetic changes; seaweed aquaculture is considered as labor-intensive business that requires some labors (Aslan, 1991; Lukas and Mondoringin, 2005). Seaweed has a large benefit and it is closely related to human life (Saifuddin, 2008).

Kupang Regency is an islands region with shoreline of $26 \mathrm{~km}$. It has potential resource especially for sizable development of seaweed aquaculture (Badan Pusat Statistik Kabupaten Kupang, 2011). Based on the data from Fisheries and Marine Services (ID: Dinas Kelautan dan Perikanan/DKP) of East Nusa Tenggara of 2010, potential and production level of seaweed in Kupang Regency ranks first compared with another regencies in East Nusa Tenggara Province, with potential for seaweed aquaculture reaches 10,354.07 ha and utilized seaweed reaches $1.035,41$ ha with reached dried seaweed by $16,566.51$ ton (Dinas Kelautan dan Perikanan Nusa 
Tenggara Timur, 2011).

Business of seaweed aquaculture in Kupang Regency is conducted by home industry, where the whole family members can actively play role in every business stages, starting from preparing cultivation area to harvest delivery. The average of total working hours for women is 210.47 and for men is 218.77 , while the children does not overwork with total time of 68.13 (Sunadji et al, 2008).

Fisheries and Marine Services of Kupang Regency has implemented policies including capital aid transfer, training of seaweed aquaculture business, post-harvesting handling, however all of these efforts still partially implemented. Hence, it needs a research on development strategy of seaweed aquaculture business in Kupang Regency, East Nusa Tenggara Province, Indonesia. (Kamlasi, 2008)

\section{Research Methodology}

This study is conducted in Kupang Regency, East Nusa Tenggara Province, starting from February to May, 2012. Used samples are seaweed cultivators who are spread in five districts in Kupang Regency. At amount of 40 respondents from the population of seaweed cultivators are taken as the sample. Sampling is conducted purposively (Nazir, 1988). Gained data forms in primary and secondary data. Primary data is gained through survey and structural interview with respondents, while the secondary data is a data that is gained from interview report with related institutions, whether government institution or private institution. Data is analyzed using SWOT analysis. SWOT analysis is an applied strategic planning method to evaluate the factors of Strengths, Weaknesses, Opportunities and Threats which may occur in achieving the goals of institution's activities on a wider scale. SWOT analysis is a part of the planning process. By following the SWOT analysis, characteristics of the main strengths, additional strengths, neutral factors, main weaknesses and additional weaknesses based on conducted internal and external environmental analysis will be gained.

Based on the internal and external analysis concept, the strengths and the weaknesses will be analyzed from the internal and external factor in a matrix that illustrate each weakness as seen in the following Table 1:

Table 1. SWOT Matrix Schema as the Planning Instrument

\begin{tabular}{|c|c|c|}
\hline External Factor & (S) STRENGTHS & (W) WEAKNESSES \\
\hline $\begin{array}{c}\text { OP) } \\
\text { OPPORTUNITIES }\end{array}$ & $\begin{array}{l}\text { SO - STRATEGY } \\
\text { Develop a strategy in utilizing } \\
\text { the Strengths (S) to utilize the } \\
\text { existing Opportunities (O) }\end{array}$ & $\begin{array}{l}\text { WO - STRATEGY } \\
\text { Develop a strategy in utilizing the } \\
\text { Opportunities (O) to overcome the } \\
\text { existing Weaknesses (W) }\end{array}$ \\
\hline (T) THREATS & $\begin{array}{l}\text { ST - STRATEGY } \\
\text { Develop a strategy in utilizing } \\
\text { the Strengths (S) to avoid the } \\
\text { Threats (T) }\end{array}$ & $\begin{array}{l}\text { Wevelop a strategy in decreasing } \\
\text { the Weaknesses (W) and avoiding } \\
\text { the Threats (T) }\end{array}$ \\
\hline
\end{tabular}


Source: Rangkuti (2009) dalam Gundo C (2011)

Qualitative characteristics in SWOT data can be developed quantitatively through SWOT analysis as developed by Pearce and Robinson (1988) in Cakarwira Gundo (2011) in order to know the exact position of the organization. The next step is to find the organization position which is shown by point $(x, y)$ in SWOT quadrants as seen in Figure 1 below:

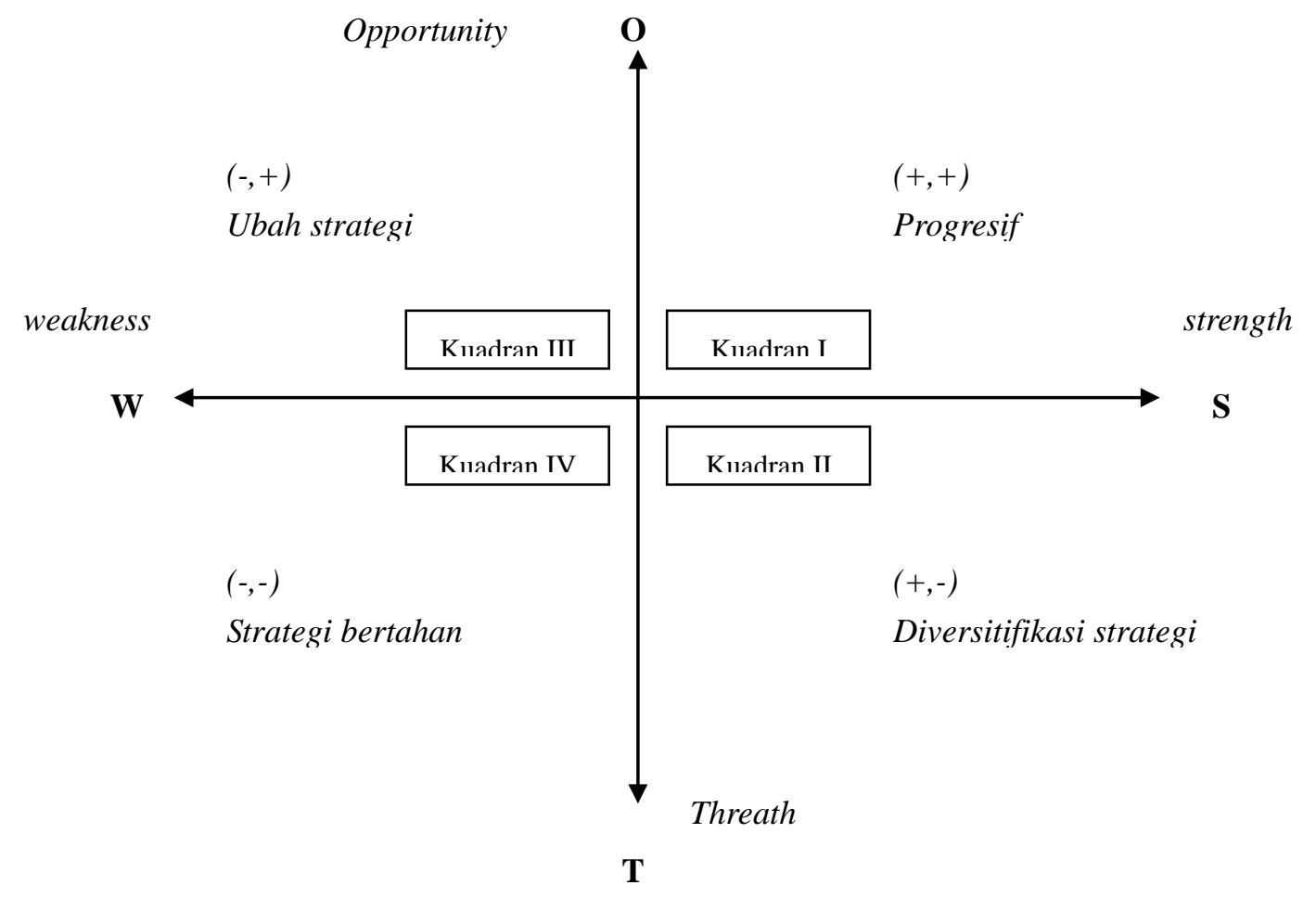

Figure 1. SWOT Quadrant of Pearce \& Robinson

Calculation of SWOT analysis is presented below:

1. Total of multiplication between weight and rating of strength and weakness are depreciated to get point X, by:

$$
\text { Point X = Strength }- \text { Weakness }
$$

2. Total of multiplication between weight and rating of opportunity and threat are depreciated to get point Y, by:

$$
\text { Point } \mathrm{Y}=\text { Opportunity }- \text { Threat }
$$

3. Results and Discussion3.1 Analysis of Internal Factor (strength and weakness)

Based on current condition evaluation and handling urgency, some internal factors (strength and weakness) affecting seaweed aquaculture business are presented in Table 2.

Table 2. The Average of Internal Factors Affecting Seaweed Aquaculture Business 


\begin{tabular}{|l|l|r|r|}
\hline Internal Factor & \multicolumn{1}{|c|}{ Indicator } & Current Condition Evaluation & Handling Urgency \\
\hline \multirow{5}{*}{ STRENGTH } & Production of seaweed & 2,178571 & 2,442857 \\
\cline { 2 - 4 } & Quality of seed & 3,778571 & 2,478571 \\
\cline { 2 - 4 } & Labor & 3,407143 & 2,271429 \\
\cline { 2 - 4 } & Quality of area & 2,75 & 2,492857 \\
\cline { 2 - 4 } & Area width & 4,328571 & 2,664286 \\
\cline { 2 - 4 } & Capital & 4,107143 & 3,064286 \\
\cline { 2 - 4 } & Marketing of seaweed & 4,457143 & 2,442857 \\
\hline \multirow{5}{*}{ WEAKNESS } & Skill & 3,135714 & 3,535714 \\
\cline { 2 - 4 } & Availability of seed & 3,25 & 2,607143 \\
\cline { 2 - 4 } & Education & 2,35 & 3,535714 \\
\cline { 2 - 4 } & Quality of seaweed & 3,792857 & 2,521429 \\
\cline { 2 - 4 } & Post-harvesting handling & 3,514286 & 2,528571 \\
\hline
\end{tabular}

Based on Table 2, it can be explained that internal factors consist of two components that are strength and weakness. Component of strength consist of seven indicators, while the weaknesses' consist of six indicators. Among those seven indicators, production of seaweed ranks the last position (2.18) meaning that the current production of seaweed is categorized as lack of production. It is caused by the occurrence of oil spill in Australian waters several years ago (Timothy, 2006). It affects on production of seaweed in some districts in East Nusa Tenggara including Kupang, thus it needs the more serious handling (by having score of 2.44). Meanwhile, quality of seed gets current assessment score by 3,78 meaning that it is quite good. It occurs because the used seed all this time is repeatedly self-produced seed, thus it is urgent to be handled by creating seed orchard, for example. For the labor by now, it is assessed enough except if there is business development that needs increment of labor numbers. For the quality of area in case of water supply in Kupang District, it is actually quite productive that is proved by the production of seaweed before the disaster of oil spill from Australian waters. Afterwards, a number of sizable production decrease occurs that reduces the productivity. The current area width is considered as good and it does not experience any problems whether in its development (because there are some areas that have not been utilized) or development arrangement. Conflict among cultivators is rarely occurred because its development arrangement is regulated and handled by the discussion among people, traditional figures and religion figures (Benny, 2007). Capital owned by the cultivators is enough because $77.86 \%$ of respondents use their own capital to run the cultivation business. The rest of respondents say that they use their own capital plus loan of rolling funds credit from the government. In the future, to develop seaweed aquaculture business, participation of government and banking are needed to facilitate bureaucracy in transferring capital aid because most of the cultivators cannot write proposal of credit request and do not have collateral (Sahri et al., 2008). Meanwhile, current seaweed marketing is quite good because no matter how much the production of seaweed is, it is still sold out, even buyers are coming to buy this product. Yet, price of seaweed which is still determined by the buyer causes bargaining power of the cultivators is low. In the future, joint handling is required in order to gain high bargaining 
power from the seller as well as to change the custom price that usually determined by the buyer (Zamroni and Yamao, 2011).

There are six indicators for weakness component that are skill, availability of seed, education, quality of seaweed and post-harvesting handling. Current skill of the cultivators are quite good although their skill tends to monotonous, thus it needs upgraded skill especially for new innovation related to the technique of seaweed aquaculture. Proved handling urgency's value for this component is 2,54. Availability of seed is also considered as weakness because sometime the cultivator gets the seed difficulty especially after west season. Thus, the seed should be wreaked from other regions that makes this problem should be handled soon, particularly for continuity of the seed availability. Education is the other weakness that affect to the business management (Sahri, et.al., 2006; Sahri., et.al 2007). Current education is considered as low that needs to be handled seriously, such as non-formal education in form of training. Quality of seaweed and post-harvesting handling are another weakness because during the handling of seaweed production, seaweed is only dried on para-para or even on the sand. This process leaves a lot of mucks that mixed into the dried seaweed, and even in rainy season, seaweed drying process spends much time. This long process wreaks fungus and causes rottenness, then post-harvesting handling efforts are needed in order to better the quality of seaweed that can increase its price (Indriani and Sumiarsih, 1999).

\subsection{Analysis of External Factor (opportunity and threat)}

External factors (opportunity and threat) affecting seaweed aquaculture business based on current condition assessment and handling urgency are presented in Table 3.

Table 3. The average of external factors affecting seaweed aquaculture business

\begin{tabular}{|l|l|r|r|}
\hline External Factor & \multicolumn{1}{|c|}{ Indicator } & Current Condition Assessment & Handling Urgency \\
\hline \multirow{5}{*}{ OPPORTUNITY } & Amount of merchants & 3,15 & 2,335714 \\
\cline { 2 - 4 } & Institutional & 2,271429 & 2,664286 \\
\cline { 2 - 4 } & Roles of government & 2,171429 & 3,014286 \\
\cline { 2 - 4 } & Price of seed & 3,464286 & 2,428571 \\
\cline { 2 - 4 } & Extension of credit & 2,878571 & 3,007143 \\
\cline { 2 - 5 } & Price of buoy & 3,292857 & 2,535714 \\
\cline { 2 - 5 } & Price of rope & 3,171429 & 2,571429 \\
\cline { 2 - 5 } & Market demand & 4,342857 & 2,485714 \\
\hline \multirow{5}{*}{ THREAT } & Price of medicaments & 4,657143 & 2,2 \\
\cline { 2 - 5 } & Education costs & 3,478571 & 2,328571 \\
\cline { 2 - 5 } & Health costs & 3,842857 & 2,435714 \\
\cline { 2 - 5 } & Food prices & 2,992857 & 2,657143 \\
\cline { 2 - 5 } & Price of seaweed & 4,942857 & 2,9 \\
\cline { 2 - 5 } & Other cultivators & 3,7 & 1,75 \\
\hline
\end{tabular}

From Table 3, it can be explained that external factors affecting seaweed aquaculture business consist of two components that is opportunity consisting of eight indicators and threat consisting of six indicators. 
Eight indicators of opportunity component consists of amount of merchants, institutional, roles of government, price of seed, extension of credit, price of buoy, price of rope and market demand. The average amounts of merchants arriving to cultivator's sites are 5-6 people. According to seaweed cultivator, this number is quite appropriate for production of seaweed (average value is 3,15). However, this number needs reparation in order to raise seller's bargaining power. Meanwhile, role of the existing institution in region of the cultivator is poor (by the average score of 2.27). This is happened because the existing institution is only a group of seaweed cultivators, hence it needs to be equipped by cooperation (Harriss, 1982). If this institution runs well, it can raise seller's bargaining power that will raise the price. By this reason, this institution is urgent to be established in order to develop seaweed aquaculture business. Additionally, role of government has not been sufficient (by score of 2, 17), therefore role of government needs to be increased not only in aspect of technical aquaculture, but also in increasing the capital by means of relevant institutions. Current price of seed is quite stable that can be assessed as quite good, but sometime its price rises because it should wreak some seeds from other region when this area cannot plant the seed during west season, for example. It is not really urgent to be handled, indeed, but this matter should be thought in order to stabilize the price of seed and to guarantee its quality. Extension of credit is considered as not sufficient all this time. It is proved that only 31 of 140 respondents can access this credit and even this credit is formed in rolling funds from relevant government service. For the future development, extension of credit is highly required. Therefore, extension of credit handling is urgent to be done including simplifying bureaucracy of credit extension in order to develop the business because it will add the capital and extend seaweed aquaculture area (Benny, 2007). Until now on, price of buoy and rope is stable, but by the development of technology, it is expected that someday these prices can decrease in order to alleviate the production cost (Miarni, 2004). Meanwhile, its handling is not really urgent considering that it depends on sectors out of fisheries field. For the last one is market demand. In the mean time, market demand is quite good by proof of absorbed power for all products. What should be noted by all people is how to raise the price of seaweed products and makes the price free from buyer's price finding.

Threat component consists of six indicators including price of medicaments, education cost, health cost, food prices, price of seaweed and other cultivators. Several years ago, seaweed cultivators use medicaments to disinfect pest. Yet, in recent year, these medicaments are not used because it is less effective as well as its increasing prices. Thus, handling level for medicaments is not urgent. Second indicator is education cost. This is not directly affect to seaweed aquaculture business meaning that if a cultivator defray education cost of his child and as time goes by, this cost raises, money that should be allocated to develop the business will be used to defray his child's education cost (Dimara, 1995). Based on result of study, education cost is quite good by the average cost of 3.47. Hence, its handling effort is not urgent considering that there is compulsory education program for Elementary School and Junior High School, then education cost is subsidized by the government. Similarity between education cost and food prices that do not directly affect to this business, price increment of education cost and food prices will hamper the development of seaweed aquaculture business. Current condition assessment for health cost is good enough by the average score of 3.7. Due to middle and minor health cost, it is enough for them to visit Community Health Center 
(Puskesmas) that cost low meaning that its handling effort is less urgent by the average score of 2.44. Although the average score of 2.84 for food prices that means enough, fluctuating nature of food prices will highly affect to business development. Result of study reveals that $81.9 \%$ of seaweed cultivators expenses are used for food. Handling effort for food prices is urgent enough. However, it cannot be handled by seaweed cultivators and relevant institution, but by all people whether the government or private institution. The next indicator is price of seaweed. As explained above, although seaweed marketing is fluent enough, seller bargaining power to determine the price is poor. Current condition evaluation on seaweed price is poor, so its handling effort is quite urgent. It needs to be conducted in order to raise bargaining power of the seller that will also raise the price of seaweed (Bamum and Squire, 1978). The last indicator considered as threat in the development of seaweed aquaculture business is other cultivators because one cultivator is competitor for the others (Flower, 2011). However, based on current assessment result for indicator of other cultivator is good with the average score of 4.94 meaning that its handling effort is less urgent. This condition is occurred because area of seaweed aquaculture that has not been utilized is quite wide. Else, role of community figures and religion figures also contributes to face the problem if there is an issue among those cultivators.

\subsection{Internal Factor Evaluation}

Based on internal factor analysis of seaweed aquaculture business, identification of some strength and weakness, then those factors can be put into IFE Table (Internal Factor Evaluation) and can be quantified. The value is calculated by weighting every factor in accordance with relative interest of company (Neori, 2008). By weight details of 0.0 (unimportant) to 1.0 (important), every factor will be calculated or ranked based on if the intended factor has:

4 = Major strength

$3=$ Minor strength

$2=$ Minor weakness

1 = Major weakness

By multiplying weight and rank, gained value of every factor will be added to get sum of total IFE values as presented in Table 4.

Table 4. Matrix of Internal Faktor Evaluation (IFE)

\begin{tabular}{|c|l|r|c|c|}
\hline Component & \multicolumn{1}{|c|}{ Indicator } & \multicolumn{1}{c|}{ Weight } & Rating & Total \\
\hline \multirow{5}{*}{$\begin{array}{c}\text { STRENGTH } \\
\text { (S) }\end{array}$} & Production of seaweed & 0.080752 & 2.442857 & 0.197266 \\
\cline { 2 - 5 } & Quality of seed & 0.095816 & 2.478571 & 0.237487 \\
\cline { 2 - 5 } & Labor & 0.08807 & 2.271429 & 0.200046 \\
\cline { 2 - 5 } & Quality of area & 0.096093 & 2.492857 & 0.239547 \\
\cline { 2 - 5 } & Area width & 0.085596 & 2.664286 & 0.228053 \\
\cline { 2 - 5 } & Capital & 0.054507 & 3.064286 & 0.167024 \\
\cline { 2 - 5 } & Marketing of seaweed & 0.08867 & 2.442857 & 0.216609 \\
\cline { 2 - 5 } & Total & 1.00 & & 1.486032 \\
\hline
\end{tabular}




\begin{tabular}{|c|c|c|c|c|}
\hline \multirow{6}{*}{$\begin{array}{c}\text { WEAKNESS } \\
\text { (W) }\end{array}$} & Skill & 0.080043 & 2.53571 & 0.20297 \\
\hline & Availability of seed & 0.083163 & 2.60714 & 0.21682 \\
\hline & Education & 0.060716 & 2.53571 & 0.15396 \\
\hline & Quality of seaweed & 0.096826 & 2.52143 & 0.24414 \\
\hline & Post-harvesting handling & 0.089747 & 2.52857 & 0.22693 \\
\hline & Total & 1.00 & & 1.04482 \\
\hline \multicolumn{4}{|l|}{ Total (X) } & 0.441212 \\
\hline
\end{tabular}

\subsection{Result of External Factor Evaluation}

From the analysis result of external environment against seaweed aquaculture business, it is identified some opportunities and threats faced by the company. These factors can be put into EFE Table (External Factor Evaluation) and calculated its value. Value is calculated by weighting every factor in accordance with relative interest of company (Sadoulet, et al., 1990). By weight details of 0.0 (unimportant) to 1.0 (important), every factor will be calculated or ranked based on if the intended factor has:

$4=$ Superior

$3=$ Above the average

$2=$ Average

$1=$ Under the average/bad

By multiplying weight and rank, gained value of every factor will be added to get sum of total EFE. Table of EFE evaluation can be seen in the following Table 5.

Table 5. Matrix of External Factor Evaluation (EFE)

\begin{tabular}{|c|c|c|c|c|}
\hline Component & Indicator & Weight & Rating & Total \\
\hline \multirow{9}{*}{$\begin{array}{l}\text { OPPORTUNITY } \\
(\mathrm{O})\end{array}$} & $\begin{array}{l}\text { Amount } \\
\text { merchants }\end{array}$ & 0.077876 & 2.335714 & 0.181895 \\
\hline & Institutional & 0.077876 & 2.664286 & 0.207483 \\
\hline & Roles of government & 0.05333 & 3.014286 & 0.160751 \\
\hline & Price of seed & 0.085681 & 2.428571 & 0.208082 \\
\hline & Extension of credit & 0.046498 & 3.007143 & 0.139825 \\
\hline & Price of buoy & 0.082019 & 2.535714 & 0.207977 \\
\hline & Price of rope & 0.078292 & 2.571429 & 0.201323 \\
\hline & Market demand & 0.082948 & 2.485714 & 0.206185 \\
\hline & Total & 1.00 & & 1.513521 \\
\hline \multirow{4}{*}{$\begin{array}{l}\text { THREAT } \\
\text { (T) }\end{array}$} & $\begin{array}{l}\text { Price } \\
\text { medicaments }\end{array}$ & 0.06618 & 2.2 & 0.14559 \\
\hline & Education costs & 0.06163 & 2.32857 & 0.14351 \\
\hline & Health costs & 0.067425 & 2.43571 & 0.16423 \\
\hline & Food prices & 0.070546 & 2.65714 & 0.18745 \\
\hline
\end{tabular}




\begin{tabular}{|l|l|r|r|r|} 
& Price of seaweed & 0.073628 & 2.9 & 0.21352 \\
\cline { 2 - 5 } & Other cultivators & 0.097681 & 1.75 & 0.17094 \\
\cline { 2 - 4 } & Total & 1.00 & & 1.02524 \\
\hline Total (Y) & & 0.488281 \\
\hline
\end{tabular}

\subsection{Development strategy}

From the calculation, gained IFE value is 2.53 and EFE value is 2.54. Based on the values, it can be arranged diagram of SWOT analysis to understand relative position of the company.

Based on the calculation above, it can be determined relative position of the company at coordinate diagram $(0.44 ; 0.49)$ that is located in the first quadrant (Figure 1$)$. It means that the company has strength and opportunity, then seaweed cultivator can utilize the existing opportunity using their owned strength. Strategy that is appropriate with position of the company is progressive or aggressive strategy to support business growth (Robledo et al., 2013)

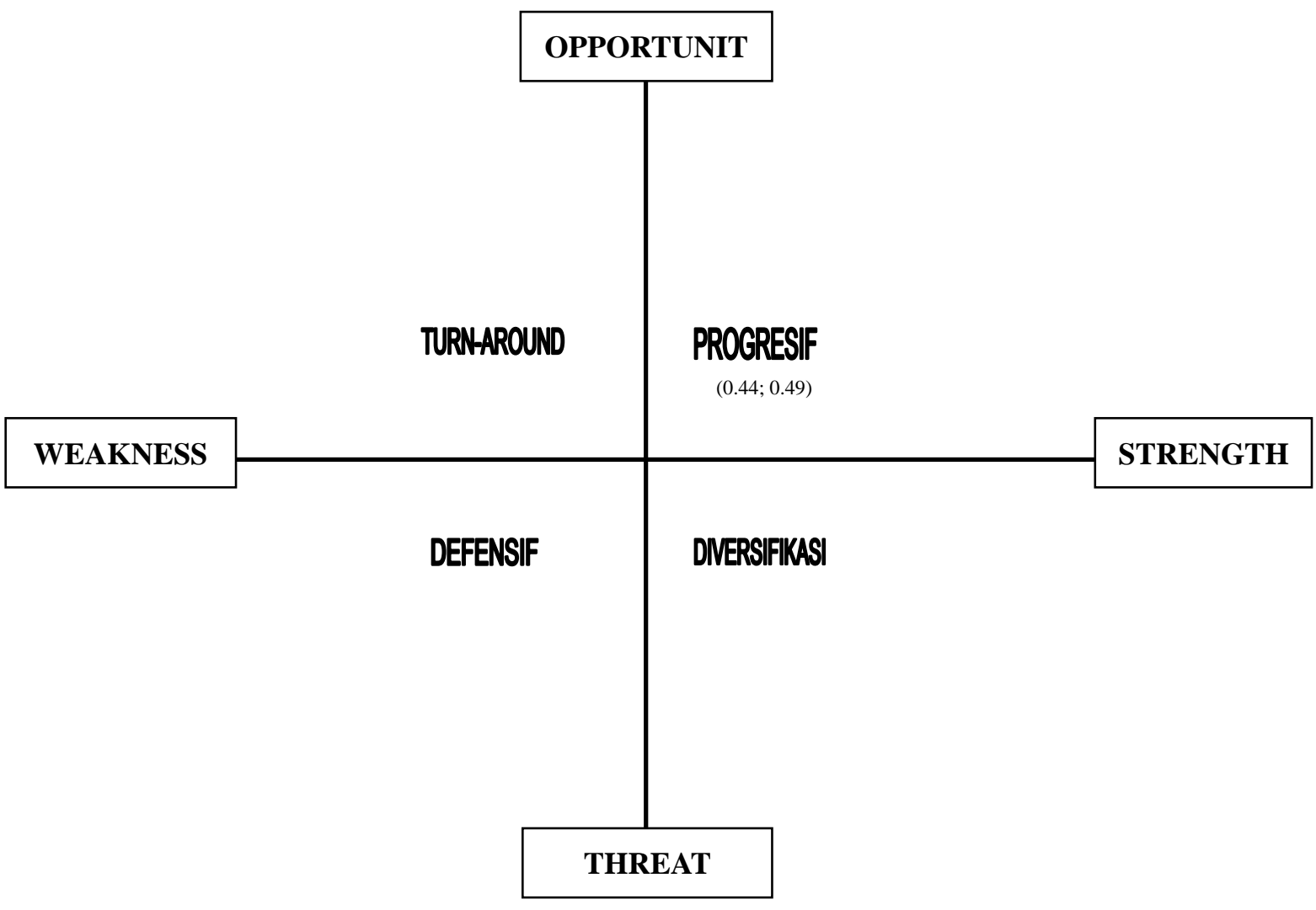

Figure 2. Relative position of seaweed aquaculture development based on SWOT analysis Progressive strategy ( $\mathrm{S}-\mathrm{O}$ strategy) is a strategy that uses the owned strength to utilize the existing opportunity, such as:

1. By elevating the amount of existing production to fulfill market demand. This can be done through extensification, a method by increasing the number of existing cultivation area 
or through an intensification (Edwin, 2001), a method that increases skill and seaweed aquaculture method (Zulham, 2008).

2. By elevating the quality and continuity of seaweed availability by increasing the role of government in the development of seaweed aquaculture in form of seed orchard, thus quality, continuity and the price of the seeds is guaranteed.

3. Utilization of the existing labor is only taken from family members, although there are some labors surrounding cultivation areas. Hence, it can enable the development of labor.

4. Available cultivation areas are quite wide with relatively low of utilization degree (20\%), then the utilization development of cultivation area to support this production elevation is widely opened.

5. Capital increment is highly required because the used capital all this time to run the business is mostly taken from personal capital (77.86\%), then by increasing the role of government in extension of credit will increase their capital in developing the business.

6. Marketing of seaweed products is quite good, but this price is still determined by the buyers causing bargaining power of the seller is still low. Hence, it needs a institutional development through cooperation, for example.

\section{Conclusion}

Relative position of the development of seaweed aquaculture based on SWOT analysis ranks in first quadrant meaning that applied strategy is Progressive or Aggressive.

Development strategy of seaweed aquaculture business progressively can be carried out by: production harvest escalation based on market demand, quality and continuity increase of seaweed, labor increment, area utilization development, capital increment, government role increment and institutional development.

\section{References}

Afrianto, E., \& dan E. Liviani. (1989). Budidaya Rumput Laut dan Cara Pengolahannya. Bharata; Jakarta.

Aslan, L. M. (1991). Budidaya Rumput Laut. Kanisius ; Yogyakarta

Badan Pusat Statistik. (2011). Kabupaten Kupang Dalam Angka, Badan Pusat statistik Kabupaten Kupang, Kupang

Bamum H. W., \& Squire I. (1978). An Econometric Application of the Teory of the Farm-Household, Journal of Development Economic, Nort Holland Publishing Company, Holland.

Benny J. A. (2007). Analisis Pengembangan Rumput Laut di Kecamatan Kupang Barat, Kabupaten Kupang, Tesis Fakultas Ekonomika dan Bisnis, UGM, Yogyakarta.

Dimara. (1995). Pengaruh Pendapatan Rumahtangga terhadap Pendidikan dalam Kemiskinan dan Kebutuhan Pokok, Rajawali Press, Jakarta. 
Dinas Kelautan dan Perikanan Provinsi Nusa Tenggara Timur. (2011). Laporan Tahunan tahun 2010. Dinas Kelautan dan Perikanan Provinsi NTT , Kupang

Direktorat Jenderal Perikanan Budidaya. (2010). Profile Rumput Laut Indonesia. Direktorat Jenderal Perikanan Budidaya. Departemen Kelautan dan Perikanan, Jakarta.

Edwin L. A. N. (2001). Kajian Intensifikasi dan Analisis Finansial Usaha Budidaya Rumput Laut Kappaphycus alvarezii di Desa Bentenan-Tumbak, Kecamatan Belang Prov. Sulawesi Utara, Tesis Program Pascasarjana IPB, Bogor.

Flower, E. M. (2011). The Impact of Seaweed farming on the socioeconomic status of coastal communities in Zanzibar, Tanzania, Worl Aquaculture Society, Baton, Rouge, LA, USA.

Harriss, J. (1982). Rural Development Theories of Peasant Economic and Agrarian Change, Hatchinson \& Co Ltd, London.

Indriani, H., \& Sumiarsih, E. (1999). Budidaya, Pengolahan, dan Pemasaran Rumput Laut (cetakan 7), Penebar Swadaya, Jakarta.

Kamlasi, Y. (2008). Kajian Ekologis dan Biologi Untuk Pengembangan Budidaya Rumput Laut (Eucheuma cottoni) di Kecamatan Kupang Barat, Kabupaten Kupang, NTT, Tesis Sekolah Pascasarjana, IPB, Bogor.

Kementerian Kelautan dan Perikanan RI. (2010). Menuju Produsen Rumput Laut Terbesar di Dunia, Kementerian Kelautan dan Perikanan RI, Jakarta.

Lukas, L., \& J. J. Mondoringin. (2005). Kajian Ekologi-Ekonomi Usaha pembudidayaan Rumput Laut di Kawasan Terumbu Karang Pulau Nain, Kabupaten Minahasa, Prov. Sulawesi Utara, Tesis Program Pascasarjana IPB, Bogor.

Miarni, V. (2004). Kajian Ekologi dan Ekonomi Rumput Laut Alami di Desa Rancapinang, Taman Nasional Ujung Kulon, Tesis Program Pascasarjana IPB, Bogor.

Nazir, M. (1988). Metode Penelitian. Jakarta: Penerbit Ghalia Indonesia.

Neori, A. (2008). Essential role of seaweed cultivation in integrated multi-trophic aquaculture farms for global expansion of mariculture: an analysis, J Appl Phycol. 20, 567-570. http://dx.doi.org/10.1007/s10811-007-9206-3

Numberi, F. (2008). Dinas Kelautan dan P erikanan, Dorong Rumput Laut sebagai Sumber Pangan dan Energi, Departemen Kelautan dan Perikanan, Jakarta.

Robledo, D., Gasca-Leyva E., \& Fraga J. (2013). Social and economic dimention of carrageenan seweed farming in Mexico, Fisheries and Aquaculture Technical Paper No. 580, FAO.

Sadoulet, E., Janvry A., \& Fatchamp, M. (1990). Peasant Household Model Behavior with Missing Market: Some Paradoxes Explaining, Economic Journal, 101, 1400-1417

Sahri M., Akhmad Y. M., \& dan Eko, G. S. (2008). Analisis factor-faktor yang mempengaruhi aksesibilitas social ekonomi nelayan kecil di Jawa Timur, Jurnal Ilmu-Ilmu Sosial Vol 18 No. 1 
Universitas Brawijaya Malang.

Sahri M., Irfan I., \& dan Eko, G. S. (2007). Saptagon. Aksesabilitas rumahtangga nelayan dalam penaggulangan kemiskinan, Jurnal Ilmu-Ilmu Sosial, 19(2) Universitas Brawijaya Malang.

Sahri, M., Irfan I., \& Eko G. S. (2006). Fishermen-Household's accessibilities to Solving Problems of their poverty: A case study in the East Java Coastal Villages, The International Journal of Acocounting and Business Society Vol 14 No 1, Postgraduate Program-Brawijaya University, Malang.

Sunadji, Crisca B. E, \& Diana J. (2008). Curahan Tenaga Kerja dan Pendapatan pada Usaha Rumput Laut di Kecamatan Sabu Timur, Kabupaten Kupang, Kupang

Syaifuddin. (2008). Hubungan Karakteristik dengan Kompetensi Pembudidaya Rumput Laut (Eucheuma spp) di Tiga Kabupaten di Provinsi Sulawesi Selatan, Disertasi. Program pascasarjana IPB, Bogor.

Timothy, P. (2006). Advances in seaweed aquaculture among Pacific Island countries, Journal of Applied Phycology (2006) 18, 227-234 Kluwer Academic Publishers. Printed in Belgium.

Zamroni, A., \& Yamao M. (2011). Coastal Resource Management: Fishermens preceptions of seaweed farming in Indonesia, World Academy of Science Engineering and Technologi 60

Zulham, A. (2008). Marjin Pemasaran dan Resiko Pedagang: Kasus Pengembangan Rumput Laut di Provinsi Gorontalo, Balai Besar Riset Sosial Ekonomi Kelautan dan Perikanan, Jakarta

\section{Copyright Disclaimer}

Copyright reserved by the author(s).

This article is an open-access article distributed under the terms and conditions of the Creative Commons Attribution license (http://creativecommons.org/licenses/by/3.0/). 